\title{
KETERLIBATAN TUTOR DALAM PENINGKATAN ANGKA PARTISIPASI KASAR (APK) MAHASISWA \\ (STUDI DI UNIVERSITAS TERBUKA UPBJJ SEMARANG)
}

\author{
Hascaryo Pramudibyanto \\ Sri Weningsih \\ Riwayat Artikel: dikirim Oktober 2018, diterima September 2018, diterbitkan September 2018
}

ABSTRAK

APK pendidikan tinggi masih lebih rendah jika dibandingkan pendidikan usia dini, SD, SMP, maupun SMA meskipun trend menunjukkan peningkatan. Fenomena ini menjadi penting mengingat pendidikan yang tinggi adalah salah satu faktor terpenting untuk menghasilkan individu yang mamiliki produktivitas tinggi. Peningkatan APK pendidikan tinggi khususnya pada mahasiswa UT tidak dapat dilepaskan dari peran tutor. Studi ini, dengan menggunakan pendekatan deskriptif kualitatif bertujuan untuk menguraikan keterlibatan tutor dalam meningkatkan APK mahasiswa UT. Hasilnya menunjukkan bahwa tutor memiliki peran dalam meningkatkan APK mahasiswa UT yang ditunjukkan dari kesediaan tutor untuk dengan senang hati terlibat dalam peningkatan APK mahasiswa UT, kesediaan tutor untuk terlibat dalam pencapaian mahasiswa baru, kesediaan tutor untuk melakukan sosialisasi, serta reward atas ketercapaian peningkatan APK mahasiswa UT.

Kata kunci : Angka Partisipasi Kasar, peningkatan, sosialisasi, keterlibatan

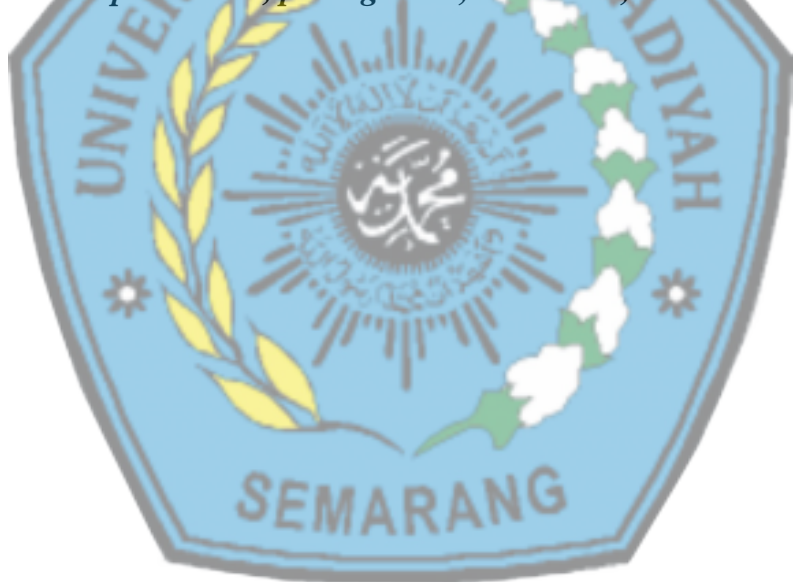




\section{PENDAHULUAN}

Aksesibilitas masyarakat terhadap pendidikan terus diupayakan oleh pemerintah. Hal ini dikarenakan keberhasilan pembangunan suatu wilayah sangat ditentukan oleh Sumber Daya Manusia (SDM) yang berkualitas. Pendidikan tinggi merupakan salah satu cara meningkatkan kualitas SDM. Oleh karena itu, peningkatan mutu pendidikan tinggi harus terus diupayakan. Saat ini, pemerintah berusaha meningkatkan partisipasi masyarakat dalam mengenyam pendidikan tinggi, dengan tidak melupakan perbaikan mutu pendidikan tinggi.

Menurut teori human capital bahwa pendidikan yang tinggi adalah salah satu faktor terpenting akan menghasilkan individu yang mamiliki produktivitas tinggi (Schultz, 1961). Semakin tinggi pendidikan individu maka semakin tinggi pula tingkat produktivitas individu tersebut dalam proses pembangunan dan menyebabkan tingkat pendapatan yang lebih tinggi juga.

Untuk dapat mengetahui tingkat aksesibilitas pendidikan tak terkecuali pendidikan tinggi, pemerintah telah menetapkan Angka Partisipasi Kasar (APK) pendidikan sebagai salah satu tolok ukurnya. Dari APK, keberhasilan pemerintah dalam sektor pendidikan tinggi juga dapat diukur.

Penetapan APK pendidikan tinggi sebagai Indikator Kinerja Utama (IKU) pada Rencana Strategis (Renstra) Kemenristekdikti 2015-2019, bertujuan untuk mengukur keberhasilan program pembangunan pendidikan tinggi yang diselenggarakan dalam rangka memperluas kesempatan bagi warga negara untuk mengenyam bangku kuliah. Perhitungan APK pendidikan tinggi dilakukan dengan cara membagi jumlah mahasiswa first entry (Diploma dan Sarjana) dengan jumlah penduduk usia 1923 tahun.

APK pendidikan tinggi dari tahun ke tahun mengalami perbaikan dan bergerak semakin baik pada periode 2011-2015 (Puspawarna Pendidikan Tinggi Indonesia, 2016). Namun, Jika dibandingkan dengan APK SD, SMP, dan SMA, APK pendidikan tinggi masih lebih rendah meskipun dalam pergerakannya mengalami peningkatan (Arsyad, 2012; Suryarama, 2009).

\section{TELAAH PUSTAKA}

\section{Partisipasi}

Sundariningrum dalam (Tokan, 2012) mengklasifikasikan partisipasi menjadi 2 (dua) berdasarkan cara keterlibatannya, yaitu:

1. Partisipasi Langsung

Partisipasi yang terjadi apabila individu menampilkan kegiatan tertentu dalam proses partisipasi. Partisipasi ini terjadi apabila setiap orang dapat mengajukan pandangan, membahas pokok permasalahan, mengajukan keberatan terhadap keinginan orang lain atau terhadap ucapannya.

2. Partisipasi Tídak Langsung Partisipasi yang terjadi apabila individu mendelegasikan hak partisipasinya.

Berdasarkan beberapa definisi di atas maka dapat disimpulkan bahwa partisipasi adalah keterlibatan suatu individu atau kelompok dalam mencapai suatu tujuan yang telah direncanakan dan adanya pembagian kewenangan atau tanggung jawab bersama-sama.

\section{Angka Partisipasi Kasar (APK)}

Untuk mengetahui nilai dari APK dapat dilakukan perhitungan dengan cara sebagai berikut:

$$
\mathrm{APK}_{\mathrm{h}}^{\mathrm{t}} \frac{\mathrm{E}_{\mathrm{h}}^{\mathrm{t}}}{\mathrm{P}_{\mathrm{h}, \mathrm{a}}^{\mathrm{t}}} \times 100
$$

\section{Keterangan:}

$\mathrm{h}$ : Jenjang pendidikan

a : Kelompok usia

$\mathrm{t}$ : Tahun

$E_{h}^{t} \quad$ : Jumlah penduduk yang pada tahun $\mathrm{t}$ dari berbagai usia sedang sekolah pada jenjang pendidikan $\mathrm{h}$ 
$\mathrm{P}_{\text {th.a }}$ : Jumlah penduduk yang pada tahun $\mathrm{t}$ berada pada kelompok usia yaitu kelompok usia yang berkaitan dengan jenjang pendidikan $h$

Semakin tinggi APK berarti semakin banyak anak usia sekolah yang bersekolah di suatu jenjang pendidikan pada suatu wilayah.

\section{Faktor yang Mempengaruhi APK}

Menurut Dreher, et al. (2006) bahwa ada faktor permintaan dan penawaran yang sangat mempengaruhi Angka Partisipasi Sekolah. Beberapa faktor permintaan yang mempengaruhi antara lain :(1) Pendapatan per kapita (kesejahteraan rumah tangga), (2) Tingkat melek huruf usia dewasa (pendidikan orang tua), (3) Jumlah sekolah dan tingkat urbanisasi penduduk. Sedangkan dari faktor penawaran yaitu (1) Rasio guru terhadap murid, (2) Biaya pendidikan, (3) Pengeluaran pemerintah di bidang pendidikan. Angka Partisipasi Kasar menurut BPS adalah proporsi anak sekolah pada usia jenjang pendidikan tertentu dalam kelompok usia yang sesuai dengan jenjang pendidikan tersebut. BPS membagi kategori menjadi 7-12 tahun, 13 - 15 tahun, 16-18 tahun dan 19-24 tahun. State of The Art Penelitian

Studi yang telah dilakukan oleh Faguet dan Sánchez (2006) dan Paula dan Pena (2007) dengan mengambil studi kasus negara Bolivia serta Spanyol mengungkapkan bahwa terjadi hubungan yang positif antara rasio murid per guru untuk menggambarkan bagaimana ketersediaan guru di suatu daerah dengan tingkat partisipasi sekolah mempunyai hubungan yang positif yang berarti dengan tersedianya guru di suatu daerah berpengaruh terhadap tingkat partisipasi sekolah. Berdasarkan temuan tersebut menunjukkan bahwa dosen (pengajar) berperan dalam menentukan APK mahasiswa.

Berpijak pada studi terdahulu tersebut, penelitian ini melakukan kajian secara deskriptif kualitatif untuk memetakan keterlibatan tutor pada Angka Partisipasi Kasar (APK) mahasiswa Universitas Terbuka UPBJJ Semarang.

\section{METODE PENELITIAN}

Jenis penelitian ini adalah penelitian deskriptif kualitatif dengan tujuan penelitian ini adalah mengungkap fakta, keadaan, fenomena, variabel dan keadaan yang terjadi saat penelitian. Sampel yang digunakan dalam studi ini adalah tutor UT UPBJJ Semarang. Metode analisis data menggunakan pendekatan Miles dan Huberman (2007) menyatakan bahwa aktivitas dalam analisis data pada penelitian kualitatif dilakukan secara interaktif dan berlangsung terus menerus sampai tuntas. Aktivitas analisis data sebagaimana yang diungkapkan tersebut meliputi tiga unsur yaitu reduksi data, penyajian data, penarikan kesimpulan.

\section{HASIL DAN PEMBAHASAN}

\section{Distribusi Jawaban Responden}

Bagian ini menguraikan temuantemuan yang menunjukkan keterlibatan tutor UT UPBJJ Semarang dalam peningkatan APK mahasiswa berdasarkan indikator-indikator yang telah ditetapkan sebagai alat ukur keterlibatan

Tabel 1

Distribusi Jawaban Pertanyaan 1

\begin{tabular}{|l|c|c|c|}
\hline \multirow{2}{*}{ Indikator } & \multicolumn{3}{|c|}{ Alternatif Jawaban } \\
\cline { 2 - 4 } & Sudah & Belum & $\begin{array}{c}\text { Pernah Tapi } \\
\text { Belum Paham }\end{array}$ \\
\hline $\begin{array}{l}\text { Mengenal istilah APK pada } \\
\text { UT }\end{array}$ & $\begin{array}{c}24 \\
(36,9 \%)\end{array}$ & $\begin{array}{c}20 \\
(30,8 \%)\end{array}$ & $\begin{array}{c}21 \\
32,3 \%)\end{array}$ \\
\hline
\end{tabular}

Sumber: Data Primer Diolah, 2019 


\section{Pertanyaan berikut menggali tentang kemampuan tutor untuk mengenali istilah APK di UT. Pada masing-masing alternatif jawaban yang disediakan, jumlah tutor yang sudah kenal \\ pernah tapi belum paham istilah APK tidak terdapat selisih yang jauh. Hal ini menunjukkan bahwa pengenalan dan pemahaman istilah APK oleh tutor masih belum cukup baik} istilah APK, belum kenal istilah APK, dan

Tabel 2

Distribusi Jawaban Pertanyaan 2

\begin{tabular}{|l|c|c|c|}
\hline \multirow{2}{*}{ Indikator } & \multicolumn{3}{|c|}{ Alternatif Jawaban } \\
\cline { 2 - 4 } & Ya & Tidak & $\begin{array}{c}\text { Masih } \\
\text { Dipertimbangkan }\end{array}$ \\
\hline $\begin{array}{l}\text { bersedia menjadi mitra UT dalam } \\
\text { peningkatan APK mahasiswa }\end{array}$ & $\begin{array}{c}62 \\
(95,4 \%)\end{array}$ & $\begin{array}{c}0 \\
(0 \%)\end{array}$ & $\begin{array}{c}3 \\
(4,6 \%)\end{array}$ \\
\hline
\end{tabular}

Sumber: Data Primer Diolah, 2019

Indikator ini menggali tentang sebanyak 62 orang $(95,4 \%)$ yang kesediaan menjadi mitra UT dalam menyatakan kesediaannnya untuk menjadi peningkatan APK mahasiswa. Terdapat mitra UT.

Distribusi Jawaban Pertanyaan 3

\begin{tabular}{|c|c|c|}
\hline \multicolumn{3}{|c|}{ Indikator $A B O$ Alternatif Jawaban } \\
\hline & Sudah Belum & Tidak Ada \\
\hline $\begin{array}{l}\text { sudah memiliki rencana untuk } \\
\text { mendukung peningkatan } \\
\text { mahasiswa UT }\end{array}$ & $\begin{array}{cc}31 & 34 \\
(47,7 \%) & (52,3 \%)\end{array}$ & $\begin{array}{c}0 \\
(0 \%)\end{array}$ \\
\hline
\end{tabular}

\section{Sumber: Data Primer Diolah, 2019}

Pertanyaan selanjutnya mengenai ketersediaan rencana untuk mendukung peningkatan APK mahasiswa UT. Terdapat 34 orang $(47,7 \%)$ yang belum memiliki rencana untuk mendukung peningkatan APK sedangkan yang sudah memiliki rencana mendukung hanya terdapat sejumlah 31 orang $(47,7 \%)$.

Tabel 4

Distribusi Jawaban Pertanyaan 4

\begin{tabular}{|l|c|c|c|}
\hline \multicolumn{2}{|c|}{ Indikator SEMHARA } & \multicolumn{3}{|c|}{ Alternatif Jawaban } \\
\cline { 3 - 5 } & Ya & Tidak & $\begin{array}{c}\text { Melihat Hak } \\
\text { dan Kewajiban }\end{array}$ \\
\hline $\begin{array}{l}\text { keberatan apabila diminta menjadi } \\
\text { mitra dalam peningkatan APK } \\
\text { mahasiswa UT }\end{array}$ & $\begin{array}{c}4 \\
(6,2 \%)\end{array}$ & $\begin{array}{c}55 \\
(84,6 \%)\end{array}$ & $\begin{array}{c}6 \\
(9,2 \%)\end{array}$ \\
\hline
\end{tabular}

Sumber: Data Primer Diolah, 2019

Indikator ini menanyakan mengenai kesediaan untuk menjadi mitra dalam peningkatan APK mahasiswa UT. Sebanyak 55 orang $(84,6 \%)$ responden menyatakan tidak. Artinya UT UPBJJ Semarang telah mendapatkan kesediaan sepenuhnya dari tutor untuk mendukung APK mahasiswa UT.

Tabel 5

Distribusi Jawaban Pertanyaan 5

\begin{tabular}{|l|c|c|c|}
\hline \multirow{2}{*}{ Indikator } & \multicolumn{3}{|c|}{ Alternatif Jawaban } \\
\cline { 2 - 4 } & $\begin{array}{c}\text { meminta } \\
\text { bahan } \\
\text { sosialisasi }\end{array}$ & $\begin{array}{c}\text { Mengumpulkan } \\
\text { calon mhsw }\end{array}$ & $\begin{array}{c}\text { Meminta } \\
\text { bantuan UPBJJ } \\
\text { untuk } \\
\text { sosialisasi }\end{array}$ \\
\hline
\end{tabular}




\begin{tabular}{|l|c|c|c|}
\hline $\begin{array}{l}\text { rencana awal mewujudkan } \\
\text { peningkatan APK mahasiswa }\end{array}$ & 34 & 3 & 28 \\
UT & $(52,3 \%)$ & $(4,6 \%)$ & $(43,1 \%)$ \\
\hline
\end{tabular}

Sumber: Data Primer Diolah, 2019

Bagian ini menggali mengenai rencana awal yang dilakukan dalam mendukung peningkatan APK mahasiswa UT. Berdasarkan hasil penelitian menunjukkan bahwa rencana awal yang dilakukan adalah meminta bahan sosialisasi dari pihak UT UPBJJ

Tabel 6

Distribusi Jawaban Pertanyaan 6

\begin{tabular}{|c|c|c|c|}
\hline \multirow[t]{2}{*}{ Indikator } & \multicolumn{3}{|c|}{ Alternatif Jawaban } \\
\hline & $\begin{array}{c}\text { keluarga } \\
\text { dekat }\end{array}$ & teman kerja & $\begin{array}{c}\text { pengurus } \\
\text { pokjar }\end{array}$ \\
\hline $\begin{array}{ll}\text { pihak yang akan dilibatkan } \\
\text { dalam rencana } & \text { kerja } \\
\text { peningkatan APK } & \text { yang } \\
\text { Bapak/ Ibu koordinir } & \\
\end{array}$ & $\begin{array}{c}4 \\
(6,2 \%)\end{array}$ & $\begin{array}{c}30 \\
(46,2 \%)\end{array}$ & $\begin{array}{c}31 \\
(47,75)\end{array}$ \\
\hline
\end{tabular}

Sumber: Data Primer Diolah, 2019

Bagian ini memberikan informasi (4) (47,7\%) menyatakan akan melibatkan mengenai pihak-pihak yang akan pengurus pokjar dan sebanyak 30 orang dilibatkan tutor dalam peningkatan APK responden $(46,2 \%)$ menyatakan akan mahasiswa UT. Sebanyak 31 orang tutor melibatkan teman kerja.

\section{Tabel 7}

Distribusi Jawaban Pertanyaan $\mathrm{Ke}-7$

\begin{tabular}{|l|c|c|c|}
\hline \multicolumn{1}{|c|}{ Indikator } & \multicolumn{3}{c|}{ Alternatif Jawaban } \\
\cline { 2 - 4 } & $\begin{array}{c}\text { pengurus } \\
\text { pokjar }\end{array}$ & $\begin{array}{c}\text { kantor UPT } \\
\text { UT (UPBJ) }\end{array}$ & dikelola sendiri \\
\hline $\begin{array}{l}\text { Tujuan } \\
\text { merekomendasikan } \\
\text { mahasiswa }\end{array}$ & $\begin{array}{c}\text { 42 } \\
(64,6 \%)\end{array}$ & $(35,4 \%)$ & $(0 \%)$ \\
\hline
\end{tabular}

Sumber: Data Primer Diolah, 2019

Berdasarkan hasil wawancara A pengurus pokjar dan sebanyak 23 orang diketahui bahwa sebanyak 42 orang responden $(35,4 \%)$ merekomendasikan responden tutor $(64,6 \%)$ akan mahasiswa kepada kantor UPT UT merekomendasikan mahasiswa kepada (UPBJJ).

Tabel 8

Distribusi Jawaban Pertanyaan Ke-8

\begin{tabular}{|l|c|c|c|}
\hline \multicolumn{2}{|c|}{ Indikator } & \multicolumn{3}{|c|}{ Alternatif Jawaban } \\
\cline { 2 - 4 } & Ya & $\begin{array}{c}\text { dilimpahkan } \\
\text { ke UPT UT } \\
\text { (UPBJJ) }\end{array}$ & $\begin{array}{c}\text { perlu } \\
\text { belajar cara } \\
\text { registrasi }\end{array}$ \\
\hline $\begin{array}{l}\text { menunjukkan cara melakukan } \\
\text { registrasi mahasiswa baru kepada calon } \\
\text { mahasiswa tersebut }\end{array}$ & $\begin{array}{c}31 \\
(47,75)\end{array}$ & $\begin{array}{c}15 \\
(23,1 \%)\end{array}$ & $\begin{array}{c}19 \\
(29,25)\end{array}$ \\
\hline
\end{tabular}

Sumber: Data Primer Diolah, 2019

Mengacu pada data yang disajikan dalam tabel diatas dapat diketahui bahwa sebanyak 31 orang responden $(47,75)$ memiliki peran untuk menunjukkan cara melakukan registrasi mahasiswa baru kepada calon mahasiswa. Sedangkan sisanya sebanyak 15 orang tutor akan melimpahkan proses registrasi mahasiswa 
baru kepada UPT UT dan 19 orang tutor menyatakan bahwa mahasiswa perlu belajar sendiri.

Tabel 9

Distribusi Jawaban Pertanyaan Ke-9

\begin{tabular}{|l|c|c|c|}
\hline \multirow{2}{*}{ Indikator } & \multicolumn{3}{|c|}{ Alternatif Jawaban } \\
\cline { 2 - 4 } & Uang & $\begin{array}{c}\text { Selalu dijadikan } \\
\text { tutor }\end{array}$ & Lainnya \\
\hline $\begin{array}{l}\text { Reward yang Bapak/ Ibu } \\
\text { harapkan dari UT }\end{array}$ & 8 & 46 & 11 \\
$(12,3 \%)$ & $(70,8 \%)$ & $(16,9 \%)$ \\
\hline
\end{tabular}

Sumber: Data Primer Diolah, 2019

Tabel diatas menunjukkan bahwa reward yang diberikan adalah keinginan reward para tutor. Sebagian dalam bentuk selalu dijadikan tutor. besar responden tutor mengharapkan

Tabel 10

Distribusi Jawaban Pertanyaan Ke-10

\begin{tabular}{|c|c|c|c|}
\hline \multirow{2}{*}{ Indikator } & \multicolumn{3}{|c|}{ Alternatif Jawaban } \\
\cline { 2 - 4 } & $\begin{array}{c}\mathrm{Rpp} 100.000 \\
\mathrm{Rp}\end{array}$ & $\mathrm{Rp} \mathrm{300.000 \textrm {sd }}$ \\
& 100.000 & s.d. 250.000 & 500.000 \\
\hline $\begin{array}{l}\text { berapa besaran minimalnya } \\
\text { untuk tiap mahasiswa yang }\end{array}$ & 5 & 22 & 38 \\
Bapak / Ibu rekomendasikan & $(7,7 \%)$ & $(33,8 \%)$ & $(58,5 \%)$ \\
\hline
\end{tabular}

Sumber: Data Primer Diolah, 2019

Tabel di atas menunjukkan reward finansial yang diharapkan tutor dalam memenuhi target pemenuhan peningkatan APK mahasiswa UT. Sebanyak 38 orang Tabel 11

Distribusi Jawaban Pertanyaan Ke-11

\begin{tabular}{|l|c|c|c|}
\hline \multicolumn{2}{|c|}{ Indikator } & \multicolumn{3}{|c|}{ Alternatif Jawaban } \\
\cline { 3 - 4 } & $\begin{array}{c}\text { Ya } \\
\text { bersedia }\end{array}$ & $\begin{array}{c}\text { sebaiknya } \\
\text { selalu diberi } \\
\text { ampuan }\end{array}$ & $\begin{array}{c}\text { ikut ketentuan } \\
\text { UT saja }\end{array}$ \\
\hline $\begin{array}{l}\text { Jika selalu dijadikan tutor, apakah } \\
\begin{array}{l}\text { Bapak/ Ibu bersedia untuk tidak } \\
\text { diberi ampuan mata kuliah apabila } \\
\text { tidak ada mata kuliah yang relevan }\end{array}\end{array}$ & $\begin{array}{c}14 \\
(21,5 \%)\end{array}$ & $\begin{array}{c}19 \\
(29,25 \%)\end{array}$ & $\begin{array}{c}32 \\
(49,2 \%)\end{array}$ \\
\hline
\end{tabular}

Sumber: Data Primer Diolah, 2019

Jawaban responden yang disajikan dalam tabel di atas menunjukkan bahwa 32 orang responden $(49,25 \%)$ akan

Tabel 12

Distribusi Jawaban Pertanyaan Ke-12

\begin{tabular}{|l|c|c|c|}
\hline \multirow{2}{*}{ Indikator } & \multicolumn{3}{|c|}{ Alternatif Jawaban } \\
\cline { 2 - 4 } & $\begin{array}{c}\text { Ya saya } \\
\text { berkompeten }\end{array}$ & $\begin{array}{c}\text { Belum tentu } \\
\text { berkompeten }\end{array}$ & $\begin{array}{c}\text { harus ada } \\
\text { pelatihan dulu }\end{array}$ \\
\hline $\begin{array}{l}\text { Jika berbentuk reward yang } \\
\text { lain, apakah Bapak/ Ibu } \\
\text { merasa berkompeten di }\end{array}$ & $\begin{array}{c}16 \\
\text { bidang itu }\end{array}$ & $\begin{array}{c}8 \\
(24,6 \%)\end{array}$ & $\begin{array}{c}41 \\
(63,1 \%)\end{array}$ \\
\hline
\end{tabular}

mengikuti aturan yang diberlakukan di UT agar dapat selalu dijadikan tutor. 
Sumber: Data Primer Diolah, 2019

Berdasarkan data yang disajikan dalam tabel di atas dapat diketahui bahwa responden tidak serta merta bersedia menerima reward. Untuk dapat menerima reward dari UT, responden menyatakan perlunya diberikan pelatihan agar responden kompeten di bidang yang dimaksud agar pantas menerima reward.

Tabel 13

Distribusi Jawaban Pertanyaan Ke-13

\begin{tabular}{|l|c|c|c|}
\hline \multicolumn{2}{|c|}{ Indikator } & \multicolumn{3}{|c|}{ Alternatif Jawaban } \\
\cline { 2 - 4 } & $\begin{array}{c}\geq 5 \\
\text { mahasiswa }\end{array}$ & $\begin{array}{c}\geq 10 \\
\text { mahasiswa }\end{array}$ & $\begin{array}{c}\geq 30 \\
\text { mahasiswa }\end{array}$ \\
\hline $\begin{array}{l}\text { Dengan jumlah minimal } \\
\text { berapa mahasiswa Bapak/ } \\
\begin{array}{l}\text { Ibu merasa } \\
\text { mendapatkan reward itu }\end{array}\end{array}$ & $\begin{array}{c}37 \\
(56,9 \%)\end{array}$ & $\begin{array}{c}23 \\
(35,45)\end{array}$ & $\begin{array}{c}5 \\
(7,7 \%)\end{array}$ \\
\hline
\end{tabular}

Sumber: Data Primer Diolah, 2019

Tabel di atas menunjukkan jumlah kepatutan minimal yang harus dipenuhi menyakatan bahwa tutor dapat tutor untuk dapat menerima reward.MU/merekomendasikan mahasiswa baru Sebanyak 37 orang responden $(56,9 \%)$ minimal lima orang.

\section{Tabel 14}

Distribusi Jawaban Pertanyaan Ke-14

\begin{tabular}{|l|c|c|c|}
\hline \multicolumn{2}{|c|}{ Indikator } & \multicolumn{3}{|c|}{ Alternatif Jawaban } \\
\cline { 2 - 5 } & $\begin{array}{c}\text { brosur, leaflet, } \\
\text { dan }\end{array}$ & $\begin{array}{c}\text { spanduk dengan } \\
\text { identitas diri }\end{array}$ & $\begin{array}{c}\text { soft file } \\
\text { presentasi }\end{array}$ \\
\cline { 3 - 5 } $\begin{array}{l}\text { Alat peraga sosialisasi } \\
\text { semacam apa saja } \\
\text { Bapak/ Ibu butuhkan }\end{array}$ & $\begin{array}{c}47 \\
(72,3 \%)\end{array}$ & $\begin{array}{c}14 \\
(6,2 \%)\end{array}$ & $(21,5 \%)$ \\
\hline
\end{tabular}

Sumber: Data Primer Diolah, 2019

Indikator ini menggali tentang menyatakan bahwa tutor perlu dibekali kebutuhan alat peraga sosialisasi untukARA alat peraga dalam bentuk brosur, leaflet meningkatkan APK mahasiswa UT. dan semacamnya untuk berkontribusi Sebanyak 47 orang $(72,3 \%)$ responden pada peningkatan APK mahasiswa UT.

Tabel 15

Distribusi Jawaban Pertanyaan Ke-15

\begin{tabular}{|l|c|c|c|}
\hline \multirow{2}{*}{ Indikator } & \multicolumn{3}{|c|}{ Alternatif Jawaban } \\
\cline { 2 - 4 } & $\begin{array}{c}100 \text { brosur/ } \\
\text { leaflet }\end{array}$ & $\begin{array}{c}2 \text { buah } \\
\text { spanduk dgn } \\
\text { identitas diri }\end{array}$ & $\begin{array}{c}\text { semua soft file } \\
\text { presentasi }\end{array}$ \\
\hline $\begin{array}{l}\text { Berapa kebutuhan alat } \\
\text { peraga sosialisasi untuk tiap } \\
\text { target wilayah itu }\end{array}$ & $\begin{array}{c}38 \\
(58,5 \%)\end{array}$ & $\begin{array}{c}9 \\
(13,8 \%)\end{array}$ & $\begin{array}{c}18 \\
(27,7 \%)\end{array}$ \\
\hline
\end{tabular}

Sumber: Data Primer Diolah, 2019

Tabel di atas menunjukkan jumlah brosur yang diperlukan tutor untuk mendukung peningkatan APK mahasiswa
UT. Terdapat 38 orang $(58,5 \%)$ orang yang menyatakan bahwa tiap tutor memerlukan 100 brosur/leaflet. 
Tabel 16

Distribusi Jawaban Pertanyaan Ke-16

\begin{tabular}{|l|c|c|c|}
\hline \multirow{2}{*}{ Indikator } & \multicolumn{3}{|c|}{ Alternatif Jawaban } \\
\cline { 2 - 4 } & $\begin{array}{c}\text { ya, } \\
\text { sanggup }\end{array}$ & $\begin{array}{c}\text { perlu ada } \\
\text { pelatihan }\end{array}$ & $\begin{array}{c}\text { tidak } \\
\text { sanggup }\end{array}$ \\
\hline $\begin{array}{l}\text { sanggup menyampaikan materi } \\
\text { sosialisasi dalam bentuk media online, } \\
\text { misalnya seperti materi yang diunggah } \\
\text { pada website UT }\end{array}$ & $\begin{array}{c}30 \\
(46,2 \%)\end{array}$ & $\begin{array}{c}31 \\
(47,7 \%)\end{array}$ & $\begin{array}{c}4 \\
(6,2 \%)\end{array}$ \\
\hline
\end{tabular}

Sumber: Data Primer Diolah, 2019

Indikator ini menyatakan bahwa terdapat 30 orang responden $(46,2 \%)$ yang menyatakan kesanggupan responden sebanyak 31 orang responden $(47,7 \%)$ menyatakan perlunya dukungan pelatihan untuk menyampaikan sosialisasi dan terkait sosialisasi UT.

Tabel 17

Distribusi Jawaban Pertanyaan Ke-17

\begin{tabular}{|l|c|c|c|}
\hline \multirow{2}{*}{ Indikator } & \multicolumn{3}{|c|}{ Alternatif Jawaban } \\
\cline { 2 - 4 } & $\begin{array}{c}\text { ya, } \\
\text { membutuhkan }\end{array}$ & tidak perlu & $\begin{array}{c}\text { bergantung } \\
\text { karakteristik } \\
\text { audiens }\end{array}$ \\
\hline $\begin{array}{l}\text { membutuhkan bantuan } \\
\text { tenaga UPT UT (UPBJJ) } \\
\text { untuk melakukan sosialisasi } \\
\text { terhadap calon mahasiswa }\end{array}$ & $(63,1 \%)$ & $(9,2 \%)$ & 18 \\
UT & & & $(27,7 \%)$ \\
\hline
\end{tabular}

Sumber: Data Primer Diolah, 2019

Temuan yang diperoleh dari bantuan tenaga UPT UT untuk melakukan pertanyaan ini adalah bahwa sebanyak 41 sosialisasi terkait peningkatan APK orang responden $(63,1 \%)$ yang "IJ' mahasiswa UT. menyatakan perlunya dukungan atau

Tabel 18

Distribusi Jawaban Pertanyaan Ke-18

\begin{tabular}{|l|c|c|c|}
\hline \multicolumn{2}{|c|}{ Indikator } & \multicolumn{3}{|c|}{ Alternatif Jawaban } \\
\hline $\begin{array}{l}\text { jumlah target calon } \\
\text { mahasiswa yang akan }\end{array}$ & 34 & 25 & $\geq 30$ orang \\
$\begin{array}{l}\text { Bapak/ Ibu usulkan pada tiap } \\
\text { semester }\end{array}$ & $(52,3 \%)$ & $(38,5 \%)$ & 6 \\
\hline
\end{tabular}

Sumber: Data Primer Diolah, 2019

Pertanyaan ini menggali mengenai menyatakan bahwa target keterlibatan jumlah target keterlibatan tutor dalam peningkatan APK mahasiswa UT. peningkatan APK mahasiswa UT adalah Sebanyak 34 orang responden $(52,3 \%)$ minimal 10 orang calon mahasiswa.

Tabel 19

Distribusi Jawaban Pertanyaan Ke-19

\begin{tabular}{|l|c|c|c|}
\hline \multirow{2}{*}{ Indikator } & \multicolumn{3}{|c|}{ Alternatif Jawaban } \\
\cline { 2 - 4 } & UT fleksibel & $\begin{array}{c}\text { UT berbiaya } \\
\text { terjangkau }\end{array}$ & UT adalah PTN \\
\hline $\begin{array}{l}\text { materi yang akan Bapak/ Ibu } \\
\text { unggulkan tentang UT }\end{array}$ & $\begin{array}{c}28 \\
(43,1 \%)\end{array}$ & $\begin{array}{c}12 \\
(18,5 \%)\end{array}$ & $\begin{array}{c}25 \\
(38,5 \%)\end{array}$ \\
\hline
\end{tabular}


Sumber: Data Primer Diolah, 2019

Pertanyaan ini menggali mengenai materi sosialisasi yang akan disampaikan tutor dalam mendukung peningkatan APK mahasiswa UT. Sebanyak 28 orang $(43,1 \%)$ menyatakan akan menyampaikan materi tentang fleksibilitas pembelajaran di UT dan juga terdapat 25 orang $(38,5 \%)$ yang akan menyampaikan tentang UT sebagai PTN dalam materi sosialisasi.

Tabel 20

Distribusi Jawaban Pertanyaan Ke-20

\begin{tabular}{|l|c|c|c|}
\hline \multicolumn{2}{|c|}{ Indikator } & \multicolumn{3}{|c|}{ Alternatif Jawaban } \\
\cline { 2 - 4 } & $\begin{array}{c}\text { ya, akan } \\
\text { diulang }\end{array}$ & $\begin{array}{c}\text { tidak } \\
\text { akan } \\
\text { diulangi }\end{array}$ & $\begin{array}{c}\text { meminta orang } \\
\text { tersebut untuk } \\
\text { mencari pengganti }\end{array}$ \\
\hline $\begin{array}{l}\text { Jika target calon mahasiswa } \\
\text { belum berhasil Bapak/ Ibu } \\
\text { dapatkan, apakah Bapak/ Ibu } \\
\text { akan mengulanginya pada } \\
\text { semester depan dengan target } \\
\text { yang sama }\end{array}$ & 57 & 6 & 2 \\
\hline
\end{tabular}

Sumber: Data Primer Diolah, 2019

Bagian ini menggali informasi Sebanyak 57 orang responden $(87,7 \%)$ tentang ketidaktercapaian target menyatakan akan mengulang target yang peningkatan APK mahasiswa UT.

\section{Tabel 21}

Distribusi Jawaban Pertanyaan Ke-21

\begin{tabular}{|l|c|c|c|}
\hline \multirow{2}{*}{ Indikator } & \multicolumn{3}{|c|}{ Alternatif Jawaban } \\
\cline { 2 - 4 } & $\begin{array}{c}\text { suka karena } \\
\text { jadi tantangan }\end{array}$ & $\begin{array}{c}\text { belum yakin } \\
\text { dengan } \\
\text { kemampuan } \\
\text { sendiri }\end{array}$ & tidak suka \\
\hline $\begin{array}{l}\text { perasaan Bapak/ Ibu jika } \\
\text { dilibatkan dalam hal ini }\end{array}$ & $\begin{array}{c}51 \\
(78,5 \%)\end{array}$ & $\begin{array}{c}14 \\
(21,5 \%)\end{array}$ & 0 \\
\hline
\end{tabular}

Sumber: Data Primer Diolah, 2019

Ekspresi kesediaan dalam pelibatan kegiatan perlu diukur. Bagian ini mengakomodir tujuan tersebut. Terdapat sebanyak 51 orang responden $(78,5 \%)$ menyatakan sangat senang dengan adanya tantang ketika dilibatkan dalam peningkatan APK mahasiswa UT.

Tabel 22

Distribusi Jawaban Pertanyaan Ke-22

\begin{tabular}{|l|c|c|c|}
\hline \multirow{2}{*}{ Indikator } & \multicolumn{3}{|c|}{ Alternatif Jawaban } \\
\cline { 2 - 4 } & ya, perlu & $\begin{array}{c}\text { tidak, karena } \\
\text { sudah punya } \\
\text { calon }\end{array}$ & $\begin{array}{c}\text { perlu, tapi } \\
\text { sifatnya } \\
\text { sementara }\end{array}$ \\
\hline $\begin{array}{l}\text { Bapak/ Ibu lebih memilih } \\
\text { berkolaborasi dengan sesama } \\
\text { tutor untuk hal ini }\end{array}$ & $\begin{array}{c}57 \\
(87,7 \%)\end{array}$ & $\begin{array}{c}5 \\
(7,7 \%)\end{array}$ & $\begin{array}{c}3 \\
(4,6 \%)\end{array}$ \\
\hline
\end{tabular}

Sumber: Data Primer Diolah, 2019

Bagian ini memberikan gambaran bahwa untuk mensukseskan program peningkatan APK mahasiswa UT, 
Tabel 23

Distribusi Jawaban Pertanyaan Ke-23

\begin{tabular}{|l|c|c|c|}
\hline \multicolumn{2}{|c|}{ Indikator } & \multicolumn{3}{|c|}{ Alternatif Jawaban } \\
\cline { 2 - 4 } & ya, yakin & $\begin{array}{c}\text { belum } \\
\text { tentu } \\
\text { juga }\end{array}$ & $\begin{array}{c}\text { yakin tapi harus dengan } \\
\text { tutor yang sudah } \\
\text { dikenal karakternya }\end{array}$ \\
\hline $\begin{array}{l}\text { berkolaborasi dengan } \\
\text { sesama tutor, akan lebih } \\
\text { menjadikan Bapak/ Ibu } \\
\text { yakin bahwa akan mampu } \\
\text { mendapatkan calon } \\
\text { mahasiswa }\end{array}$ & $\begin{array}{l}40 \\
(61,5 \%)\end{array}$ & $\begin{array}{c}12 \\
(18,5 \%)\end{array}$ \\
\hline
\end{tabular}

Sumber: Data Primer Diolah, 2019

Bagi 40 orang responden $(61,5 \%)$ pihak yang berkolaborasi untuk mencapai menyatakan bahwa kolaborasi dengan target peningkatan APK mahasiswa UT. sesama tutor akan meyakinkan pihak-

\section{Tabel 24}

Distribusi Jawaban Pertanyaan Ke-24

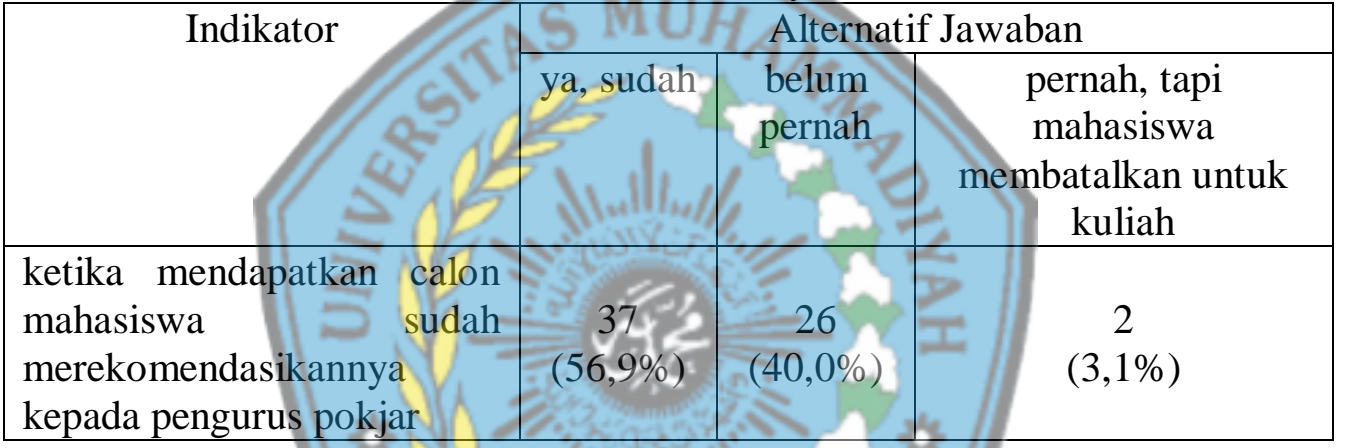

\section{Sumber: Data Primer Diolah, 2019}

Sebanyak 37 orang responden direkomendasikan kepada pengurus $(56,9 \%)$ menyatakan bahwa calon pokjar mahasiswa yang diperoleh akan

\section{KESIMPULAN}

1. Pada umumnya tutor belum mengerti dan memahami tentang APK mahasiswa UT. Oleh karenanya banyak tutor yang belum memiliki rencana atau program yang dapat dilakukan untuk terlibat dalam peningkatan APK mahasiswa UT. Meskipun demikian, tutor memiliki kesediaan untuk terlibat dalam peningkatan APK mahasiswa UT yang ditunjukkan dari kesediaan untuk menjadi mitra dan kesediaan untuk melakukan sosialisasi
2. Untuk melakukan sosialisasi UT, tutor menyatakan perlunya pelatihan dan dukungan dari UT. Pelatihan dilakukan sebelum tutor melakukan sosialisasi secara mandiri sedangkan dukungan diwujudkan dalam bentuk brosur/lealfet atau sejenisnya serta bantuan narasumber.

3. Keterlibatan tutor dalam peningkatan APK mahasiswa UT sangat diperlukan. Berdasarkan temuan dalam studi ini menyatakan bahwa tutor bersedia untuk diberikan target capaian mahasiswa baru.

4. Penghargaan atas ketercapaian target dalam peningkatan APK mahasiswa 
oleh tutor diberikan dalam bentuk pemberian jadwal tutorial secara reguler

\section{DAFTAR PUSTAKA}

Arsyad, Lincolin. (2012). Ekonomi Pembangunan. Tanggerang: Percetakan Universitas Terbuka.

Dreher, George F and Thomas W Dougherty. (2006). Human Resources Strategy. Mc Graw Hill. Singapore.

Faguet, J.P dan F. Sánchez. (2006). Decentralization's Effects of Educational. Outcomesin Bolivia and Colombia. The Suntory Centre Suntoryand Toyota.

Miles, Mattew B \& A. Michael Huberman. (2007). Analisis Data Kualitatif. Buku sumber tentang metode- metode baru. Jakarta: Universitas Indonesia. Press

Schultz, Theodore W. (1961). Investment in Human Capital. The American Economics Review. No. 51.
Septiana, Citra dan Hutapia (2008) "Analisis Faktor-faktor yang Mempengaruhi Angka Partisipasi Sekolah di Sumatra", Thesis Fakultas Ekonomi, Universitas Bengkulu.

Suryarama, S. (2009). Peran Yayasan Dalam Pengelolaan Bidang Pendidikan Pada Perguruan Tinggi Swasta. Jurnal Organisasi Dan Manajemen, 5(1), 55-62.

Tokan, Ferdinand B (2012). Partisipasi Warga Sekolah dalam Pelaksanaan Program Pendidikan Inklusif di SD Negeri Gejayan. Skripsi, FIP Universitas Negeri Yogyakarta. Diunduh melalui http://eprints.uny.ac.id/7720/3/bab 202\%20\%20\%2007110241010.pdf pada hari Senin, 21 Maret 2019 pukul 15.53 